\title{
Three-dimensional structure of the skeleton and buccal diverticulum of an acorn worm Saccoglossus mereschkowskii Wagner, 1885 (Hemichordata: Enteropneusta)
}

\author{
O.V. Ezhova, V.V. Malakhov \\ Moscow State University, Biological Faculty, Department of Invertebrate Zoology; Leninskie Gory, \\ 1, bldg. 12, Moscow, 119991 Russia. \\ e-mail:olga_ejova@mail.ru; vmalakhov@inbox.ru
}

\begin{abstract}
We describe and illustrate the morphology of unpaired proboscis skeleton and buccal diverticulum of a hemichordate Saccoglossus mereschkowskii for the first time and compare them to homologous structures in other species. The proboscis skeleton is a unique structure found only in enteropneust hemichordates. It is made of cartilaginous-like material and supports the buccal diverticulum. The proboscis skeleton is a Y-shaped organ, which consists of the unpaired anterior plate and two posterior horns. The anterior part of the plate bears the conical rostrum with the two symmetrical supporting saucers on each side. The ventral side bears a central fossa. A pair of lateral wings extends on each side of the proboscis skeleton. The ventral keel passes along the ventral midline. The horns are curved symmetrical outgrowths separating the flattened diverticulum base from the buccal tube. The buccal diverticulum consists of three main parts: the flattened base, the isthmus and the hood-shaped anterior region, supported by the skeletal rostrum. The isthmus consists of the axial part with a small spherical lumen. The base of diverticulum anterior part has three outpocketings: one ventral and two lateral. The skeleton growths fit the appropriate depressions of the buccal diverticulum surface. The morphology of the skeleton and the buccal diverticulum in enteropneusts varies from species to species and can serve as a potentially useful taxonomic character.
\end{abstract}

KEY WORDS: Saccoglossus mereschkowskii, proboscis skeleton, buccal diverticulum, morphology, taxonomy.

\section{Трёхмерная структура скелетного элемента и буккального дивертикула Saccoglossus mereschkowskii Wagner, 1885 (Hemichordata: Enteropneusta)}

\author{
О.В. Ежова, В.В. Малахов
}

\begin{abstract}
Московский государственный университет им. М.В. Ломоносова, Биологический факультет, кафедра зоологии беспозвоночных; Ленинские горы, 1, стр. 12, Москва, 119991 Россия. e-mail: olga_ejova@mail.ru; vmalakhov@inbox.ru
\end{abstract}

Printed in 2010 
РЕЗЮМЕ: Методами гистологической техники изучена морфология непарного скелетного элемента и буккального дивертикула Saccoglossus mereschkowskii Wagner, 1885. По сериям срезов составлена трехмерная реконструкция этих образований; проведено сравнение с гомологичными структурами других видов. Непарный скелетный элемент - это уникальная структура, свойственная только кишечнодышащим. Он образован хрящеподобным веществом и служит опорой для буккального дивертикула. Скелетный элемент - это Ү-образный орган, состоящий из непарной передней пластинки и пары задних рожек. Спереди на непарной пластинке располагается конический рострум, а также две симметричные подставки с каждой стороны. На вентральной стороне имеется центральная ямка, от которой спереди назад проходит вентральный киль. По бокам непарной пластинки располагаются латеральные крылья скелетного элемента. Рожки представляют собой изогнутые симметричные отростки, отделяющие уплощённое основание буккального дивертикула от кишечной трубки. Буккальный дивертикул состоит из трёх основных частей: уплощённого основания, перешейка и колпачковидной передней части, опирающейся на рострум скелетного элемента. В перешейке выделяется осевая часть с небольшим округлым просветом. В основании передней части буккального дивертикула имеется три своеобразных кармана: один вентральный и два латеральных. Рострум скелетного элемента вдаётся в ткань буккального дивертикула, образуя в ней соответствующее углубление. Морфология скелетного элемента и буккального дивертикула различается у разных видов кишечнодышащих и может использоваться в таксономии этой группы.

КЛЮЧЕВЫЕ СЛОВА: Saccoglossus mereschkowskii, скелетный элемент, буккальный дивертикул, морфология, таксономия.

\section{Introduction}

Enteropneusts, commonly known as acorn worms, are burrowing marine animals, which form a class in the phylum Hemichordata. The class includes about 70 species, distributed into five families: Protoglossidae, Harrimaniidae, Spengelidae, Ptychoderidae, and Saxipendidae. The enteropneust body comprises three morphologically distinct regions: the anterior muscular proboscis (protosome), the short collar (mesosome), and the long trunk (metasome) with numerous gill slits. The proboscis narrows posteriorly to the slender proboscis stalk, joining the proboscis with the collar (Hyman, 1959; Benito, Pardos, 1997).

Hemichordates possess a series of features permitting them to be considered a group closely connected with Chordate (Bateson, 1886; Beklemishev, 1964; Fedotov, 1966; Ruppert et al., 2004). One of the characteristics which may be interpreted as a similarity between hemichordates with the chordates is the internal skeleton complex. This complex includes a buccal diverticulum $^{1}$ (the functional skeleton of hemichordates), an unpaired cartilaginous wishbone in the stalk between the collar and proboscis, and the cartilaginous gill bars. These structures have been known for a long time (Spengel, 1893; Van der Horst, 1939; Hyman, 1959), however their detailed morphology has been studied in a relatively small number of species (Van der Horst, 1939; Hyman, 1959). Recent morphological studies on different enteropneusts concern of electronic structure to a greater extent than detailed morphology (Benito, Pardos, 1997; Cameron, 2002; Jianmey, Xinzheng, 2005).

Hyman recommends "buccal diverticulum" since words formed from "chord" seem to imply a solid construction.

${ }^{1}$ We use term "buccal diverticulum" instead of "stomochord" in the wake of Hyman (1959). 
We describe the proboscis skeleton and the buccal diverticulum of Saccoglossus mereschkowskii Wagner, 1885 and compare its morphology to the homologous structures in other species of hemichordates .

\section{Material and methods}

As material for this study, we used four specimens of Saccoglossus mereschkowskii collected at the White-Sea Biological Station of Moscow State University in the Kandalaksha Bay of the White Sea at a depth of 5-10 m from a muddy substrate. The animals were fixed in Bouin's picri-formal-acetic fixative and then transferred and stored in $70 \%$ ethanol. Specimens were dehydrated in a standard alcohol series, embedded in paraplast (Paraplast Embedding Media; SIGMA. The melting point temperature $60^{\circ} \mathrm{C}$ ), and serially sectioned at 7 $\mu \mathrm{m}$. Sections were stained with hematoxylin, mounted in canada balsam and viewed and photographed on a Zeiss Axioplan 2 Imaging microscope equipped with a camera (AxioCam Hrm Zeiss). We made four series of sections: one transverse, one frontal and two sagittal. The three-dimensional structure of the proboscis skeleton and buccal diverticulum was restored with the method of projecting reconstruction by W. His (Ivanov et al., 1981). Images of the organ of interest were collected separately from each section and further manipulated in Adobe Photoshop CS 8.0 to create a 3D model.

Abbreviations for figures: aldb - alae laterales diverticuli buccalae; aldbd - ala lateralis diverticuli buccalae dexter; aldbs — ala lateralis diverticuli buccalae sinister; ali - alae laterales isthmi; alid - ala lateralis isthmi dexter; alis - ala lateralis isthmi sinister; alsk alae laterales skeletale; alskd - ala lateralis skeletale dexter; alsks - ala lateralis skeletale sinister; bas - basis diverticuli buccalae; bd buccal diverticulum; bt - buccal tube; c collar; canc — canales cornuum; cancd - canalis cornuum dexter; cancs - canalis cornuum sinister; cand - canalis dorsalis diverticuli buccalae; cbsin - central blood sinus; cc - collar coelom; cor — corni; cord — cornus dexter; cors - cornus sinister; crefc - crista circumflexa fossae centralis; crdmv - crista divisioria mediana ventralis; $\mathrm{cv}$ - carina ventralis; $\mathrm{ep}$ epithelium; fc - fossa centralis; fsub - fossae subiculi; g — gut; gl — glomerulus; gw - gut wall; hv - heart vesicle; i - isthmus diverticuli buccalae; lisk — lamina imparis skeletale; lum lumen of buccal diverticulum; $\mathrm{m}$ - mouth; nc nerve cord; $\mathrm{nl}$ - nerve layer; pa - pars anterior diverticuli buccalae; pai — pars axialis isthmi; pc — perihaemal coelom; pd - paries dorsalis diverticuli buccalae; pr — proboscis; prc proboscis coelom; pred - proboscis coelomoduct; $\mathrm{rdb}$ - rostrum diverticuli buccalae; rsk - rostrum skeletale; sacl — saccus lateralis; sacv — saccus ventralis; st - stalk; sub subiculi; $\mathrm{t}$ - trunk; trest — transverse constrictions; vlisk — vagina laminae imparis skeletale; $\mathrm{vr}$ - vagina rostri.

Обозначения на рисунках: aldb - латеральные крылья буккального дивертикула; aldbd - правое латеральное крыло буккального дивертикула; aldbs - левое латеральное крыло буккального дивер-тикула; ali латеральные крылья перешейка; alid - правое латеральное крыло перешейка; alis левое латеральное крыло перешейка; alsk латеральные крылья скелетного элемента; alskd - правое латеральное крыло скелетного элемента; alsks — левое латеральное крыло скелетного элемента; bas - основание буккального дивертикула; bd - буккальный дивертикул; bt - кишечная трубка; c - воротничок; canc - канальцы рожек; cancd - правый каналец рожек; cancs — левый каналец рожек; cand - дорсальный канал буккального дивертикула; cbsin центральный кровеносный синус; сc - воротничковый целом; cor - рожки; cord правый рожек; cors - левый рожек; crcfc окаймляющий гребень центральной ямки; crdmv - вентральный разделительный гребень; cv — вентральный киль; ер - эпителий; fc - центральная ямка; fsub - ямки подставок; g - кишка; gl - гломерулюс; gw - стенка кишки; hv — перикардиальный целом; i - перешеек буккального дивертикула; lisk - непарная пластинка скелетного 
элемента; lum — просвет буккального дивертикула; m - рот; пс - нервная трубка; $\mathrm{nl}$ - нервный слой; ра - передняя часть буккального дивертикула; раі - осевая часть перешейка; pc - перигемальный целом; pd дорсальная стенка буккального дивертикула; $\mathrm{pr}$ - хоботок; prc - хоботковый целом; prcd - хоботковый целомодукт; rdb - pocтрум буккального дивертикула; rsk - рострум скелетного элемента; sacl — латеральный карман; sacv - вентральный карман; st - стебелёк; sub - подставки; t - туловище; trcst - поперечные перетяжки; vlisk влагалище непарной пластинки скелетного элемента; vr - влагалище рострума.

\section{Results}

Skeleton is an inverted-Y-shaped structure situated in the proboscis stalk which connects the collar and the proboscis body regions (Fig. 1). The skeleton constitutes a thickening of the basal lamina between the endodermal epithelia of pharynx and buccal diverticulum as well as the endodermal epithelium of buccal diverticulum and the ectodermal epithelium of proboscis. The skeleton consists of an unpaired plate (lamina imparis skeletale) directed forward along the stalk to proboscis and paired horns (corni) extended backwards to the collar region on each side of buccal tube. The skeleton was $1.2 \mathrm{~mm}$ long in the largest specimen studied; the horns accounting for about $55 \%$ of total skeleton length $(0.7 \mathrm{~mm})$.

The anterior part of the unpaired plate consists of a conical rostrum with symmetrical lateral supporting saucers (subiculi) (Fig. 2). The rostrum nests in a depression of the buccal diverticulum (see below), while the subiculi positionally correspond to the paired lateral invaginations of proboscis epidermis and the buccal diverticulum depressions. There is the central invagination or fossa (fossa centralis) at the level of the subiculi on the ventral side of skeleton. Fossa centralis is confined by a bordering ridge (crista circumflexa fossae centralis) on each side (Fig. 2À). A pair of lateral wings (alae laterales) extends on each side of the skeleton from the base of subiculi to the narrowest portion of the unpaired plate. The midventral keel (carina ventralis) extends from the posterior margin of the fossa centralis (Fig. $2 \hat{\mathrm{A}}$ ). Lamina imparis skeletale is convex on the dorsal side and lacks surface modifications.

The posterior part of the proboscis skeleton is divided into the paired horns (corni). The horn tips are situated in the middle of the collar region (Fig. 1). Corni are curved symmetrical tapered outgrowths (Fig. 2). In transverse sections the horns appear laterally compressed and turned at an angle of 45 degrees with respect to the frontal plane of the animal (Figs 3C, D).

Buccal diverticulum (diverticulum buccalae) represents a blind anterior outpocketing of the buccal tube (Figs 4, 5). Its length in the largest studied specimen was $1.3 \mathrm{~mm}$. The buccal diverticulum consists of three main parts: the flattened base, the isthmus, and the anterior hood (Fig. 6).

The buccal diverticulum base (basis diverticuli buccalae) is the area, where the dorsal wall of the gut forms the dorsal and ventral walls of the diverticulum. In the collar region the dorsal epithelium of the gut is histologically different from the ventral and lateral epithelium (Fig. 7). It is thicker $175 \mu \mathrm{m}$ (compared to no more than $70 \mu \mathrm{m}$ ), is vacuolated, and appears lighter then the lateral and ventral epithelium of the gut. The dorsal wall of the gut forms a groove (canalis dorsalis diverticuli buccalae) corresponding to the nerve tube and the underlying perihaemal coeloms (Figs 3, 6B).

There is no distinct boundary between the modified epithelium of the dorsal wall of the gut and the dorsal wall of the buccal diverticulum (paries dorsalis diverticuli buccalae). The groove which contains the nerve tube and the perihaemal coeloms continues as the dorsal wall of the buccal diverticulum. The ventral wall of the buccal diverticulum joins with the dorsal wall of the gut in the anterior third of collar region, forming an anteriorly directed $\mathrm{V}$-formed boundary.

The base of the buccal diverticulum is dorso-ventrally compressed. The lumen of the diverticulum is continuous with the lumen of the 


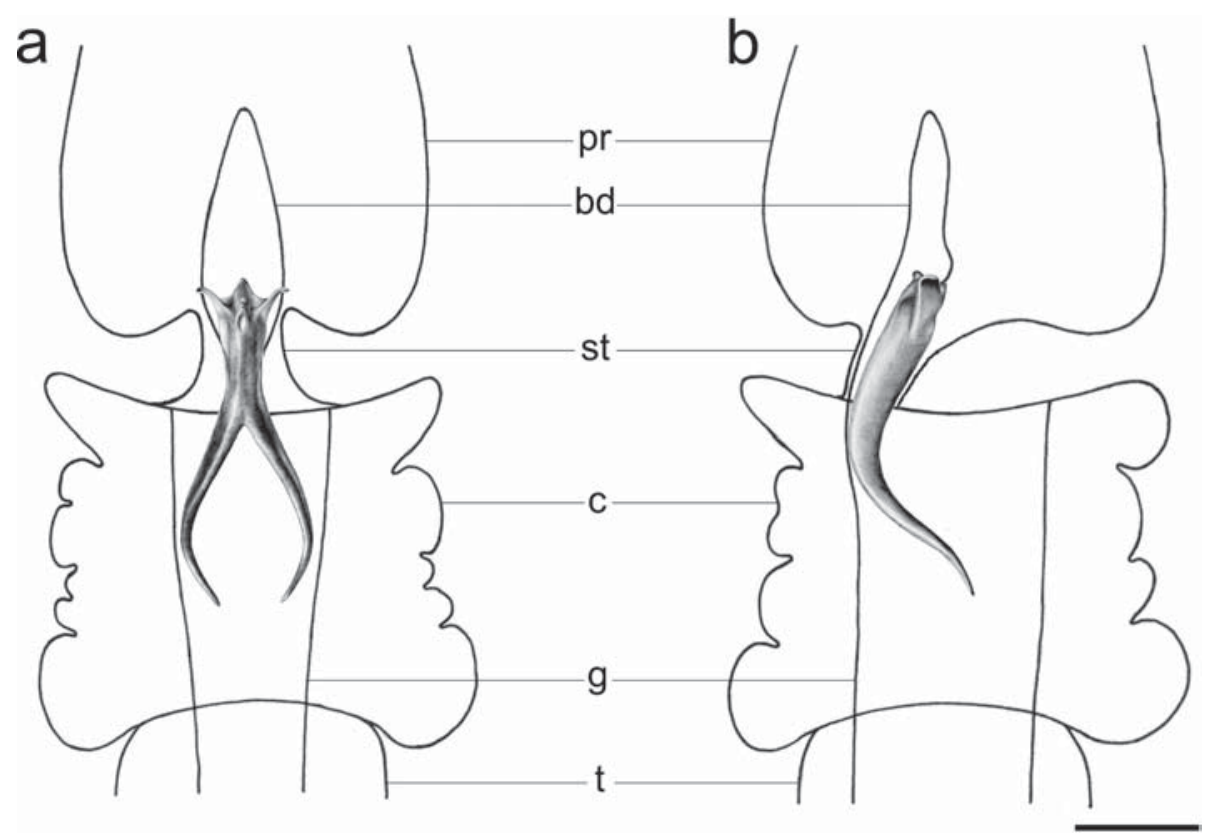

Fig. 1. Location of the stalk skeleton (shaded) of Saccoglossus mereschkowskii. A - ventral view; B - lateral view. Scale bar $500 \mu \mathrm{m}$.

Рис. 1. Расположение непарного скелетного элемента (заштрихован) в теле Saccoglossus mereschkowskii. А — вид с вентральной стороны; В — вид сбоку. Масштаб $500 \mu \mathrm{m}$.

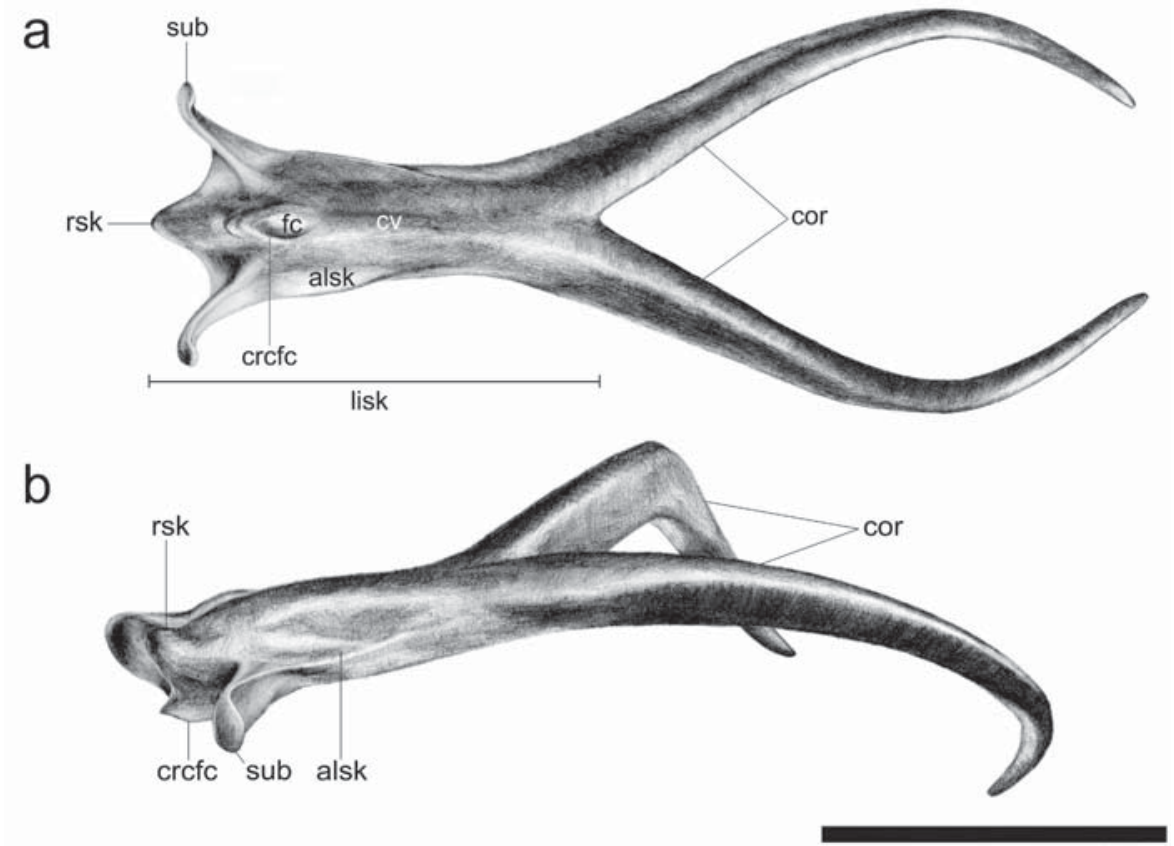

Fig. 2. Unpaired stalk skeleton of Saccoglossus mereschkowskii.

A - ventral view; B - lateral view (twisted). Scale bar $500 \mu \mathrm{m}$.

Рис. 2. Непарный скелетный элемент Saccoglossus mereschkowskii.

А — вид с вентральной стороны; В — вид сбоку (под углом). Масштаб $500 \mu \mathrm{m}$. 


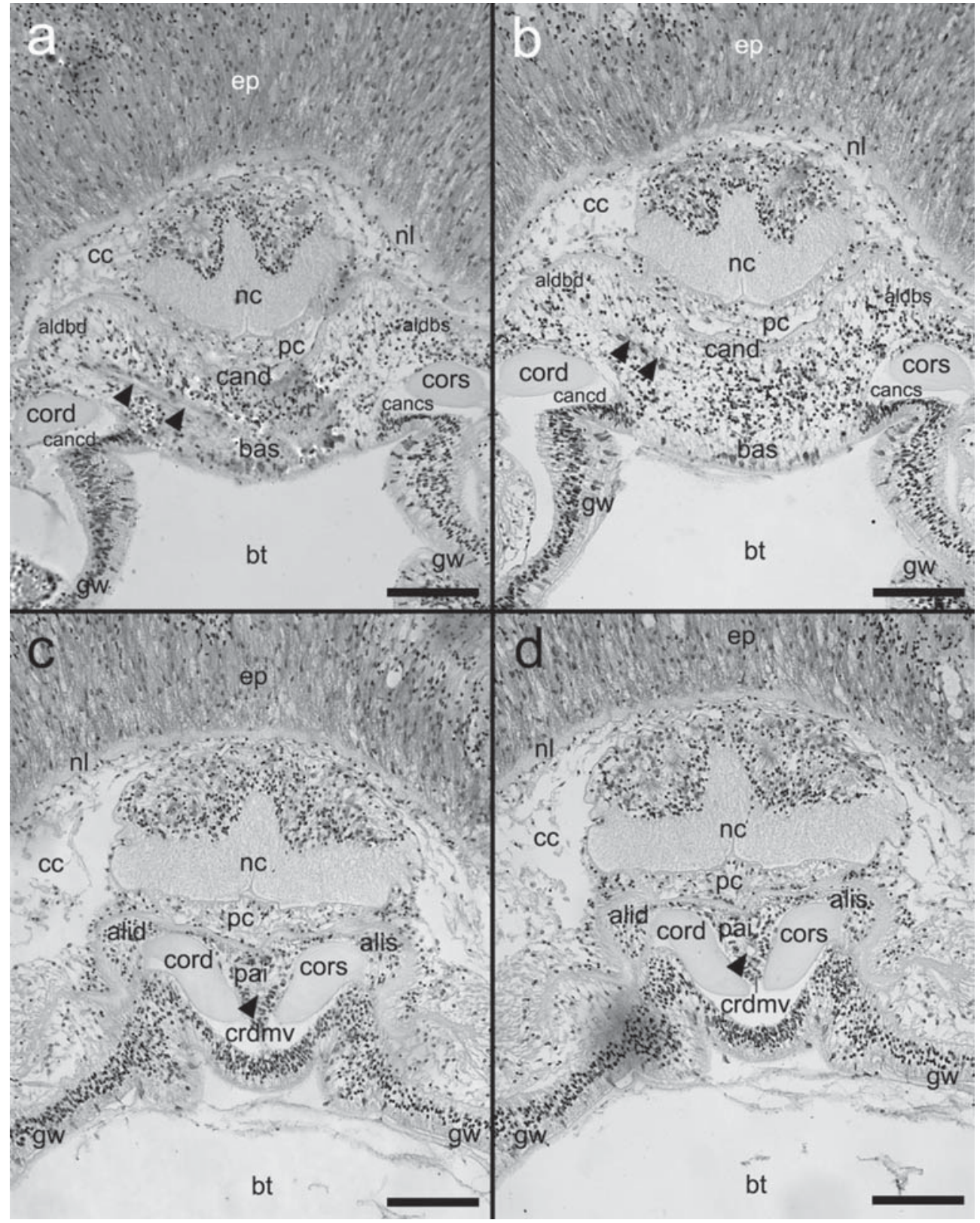

Fig. 3. Transverse sections through the collar of Saccoglossus mereschkowskii from posterior (A) to anterior (D).

LM. Arrows indicate the lumen of the buccal diverticulum. Scale bar $100 \mu \mathrm{m}$.

Рис. 3. Серия поперечных срезов через воротник Saccoglossus mereschkowskii сзади (А) кпереди (D). Световой микроскоп. Стрелками указан просвет буккального дивертикула. Масштаб $100 \mu \mathrm{m}$. 


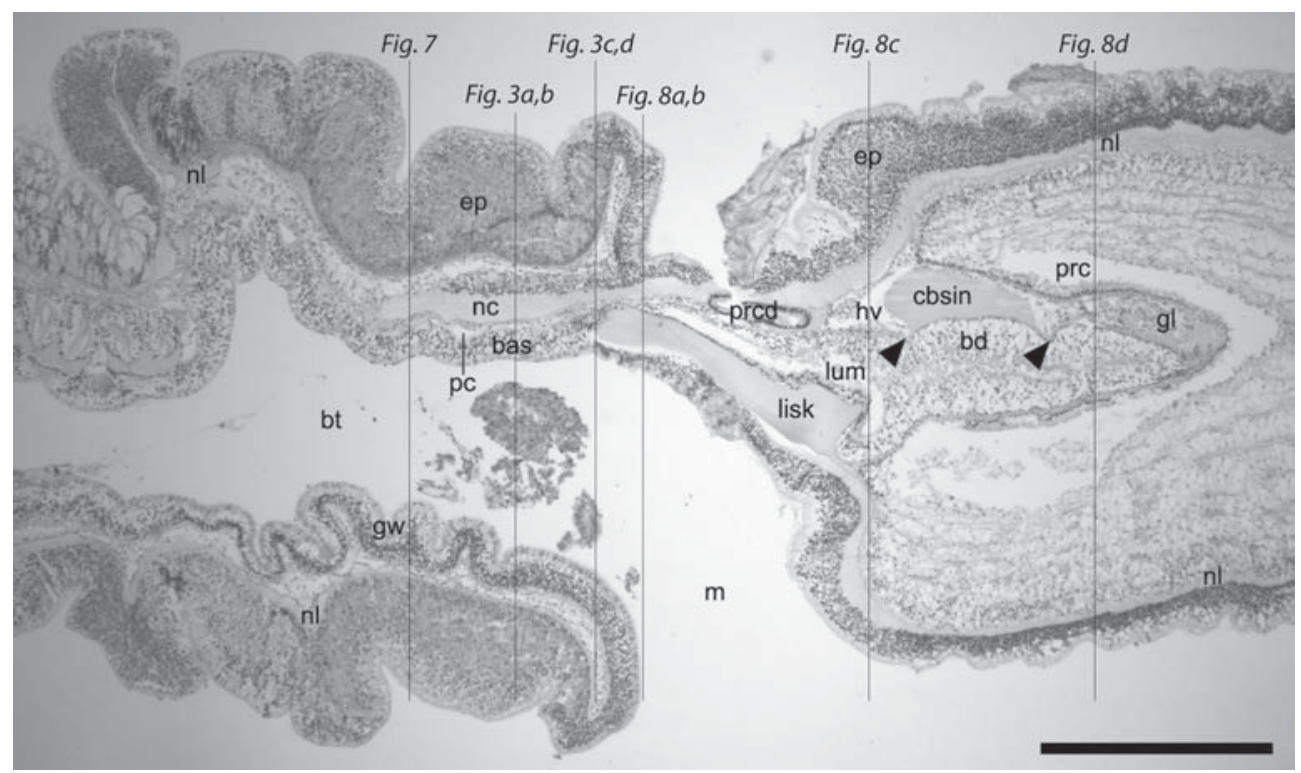

Fig. 4. Sagittal section through the proboscis, stalk, and collar of Saccoglossus mereschkowskii. LM. The arrows point to transverse constrictions of the diverticulum rostrum. The vertical lines mark the level of the transverse sections. Scale bar $500 \mu \mathrm{m}$.

Рис. 4. Сагиттальный срез через хоботок, стебелёк и воротничок Saccoglossus mereschkowskii. Световой микроскоп. Стрелками указаны поперечные перетяжки рострума буккального дивертикула. Вертикальными линиями отмечены участки, через которые проходили поперечные срезы. Масштаб $500 \mu \mathrm{m}$.

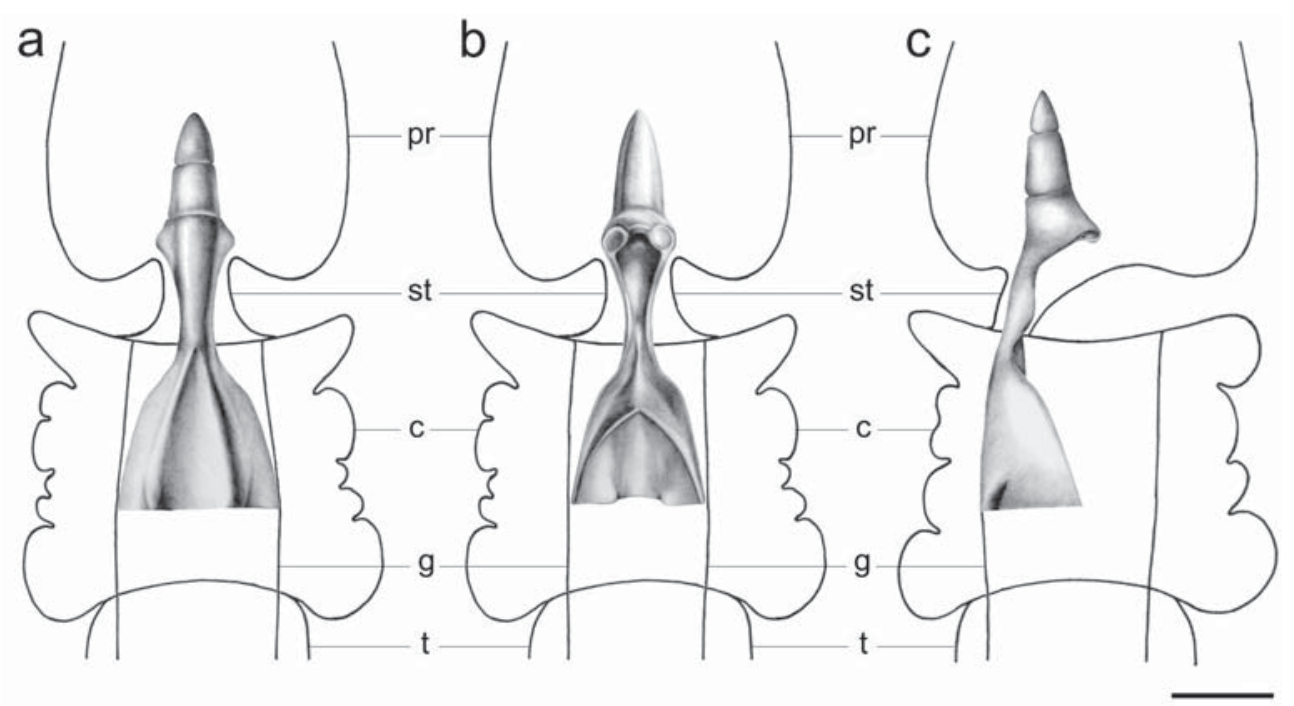

Fig. 5. Location of the buccal diverticulum (shaded) of Saccoglossus mereschkowskii. A - dorsal view; B - ventral view; C - lateral view. Scale bar $500 \mu \mathrm{m}$.

Рис. 5. Расположение буккального дивертикула (заштрихован) в теле Saccoglossus mereschkowskii. А — вид с дорсальной стороны; В — вид с вентральной стороны; С — вид сбоку. Масштаб $500 \mu \mathrm{m}$. 
gut cavity. In transverse sections the lumen of the diverticulum appears as a narrow transverse slit (Fig. 3A). In some sections the lumen may be reduced due to strong development of vacuolated epithelium of the buccal diverticulum (Fig. 3B).

The dorsal part of the gut is separated from the lateral parts by the skeletal horns. Gut epithelium surrounds the horns both from the inside and outside. Folds of the gut epithelium surround the horns from the outside continuing forward and giving rise to the lateral wings of the diverticulum (alae laterales diverticuli buccalae) (Fig. 3). The skeletal horns adjoin the buccal diverticulum latero-ventrally and are housed within the special grooves of the buccal diverticulum (canales cornuum). The buccal diverticulum forms the ventral ridge (crista divisioria mediana ventralis) between the horns (Figs 3C, D, 6A, C). The ridge runs from the horns' closure to the middle of diverticulum isthmus.

The isthmus (isthmus diverticuli buccalae) is the narrowest part of the buccal diverticulum (Fig. 6). In transverse sections it consists of an axial part (pars axialis isthmi) with a small rounded lumen and the wings (alae laterales isthmi) which surround the skeleton laterally (Fig. 8A). The transverse diameter of the buccal diverticulum increases from the mouth to the base of the proboscis. The isthmus is semicircular in the transverse sections with ventrally directed cusps (Fig. 8B). Ventral invagination of the wall of the buccal diverticulum is closely fits the unpaired plate of the skeleton (vagina laminae imparis skeletale). At this level, the epithelium of the diverticulum is differentiated into dorsal lightly staining vacuolated region and the ventral region comprised of columnar ciliated cells (Fig. 8B).

The anterior part of the buccal diverticulum (pars anterior diverticuli buccalae) is hoodshaped. The rostrum of the diverticulum (rostrum diverticuli buccalae) is conical and has irregular transverse constrictions (Figs 4, 6B, C).

The skeletal rostrum supports the anterior part of diverticulum from the ventral side. At the same time subiculi fit the appropriate depressions of the diverticulum. The rostrum of the skeleton fits the conical depression (vagina rostri) at the base of the anterior part of the diverticulum. The base of the anterior part of the diverticulum has three pouches: one ventral (saccus ventralis) and two lateral (sacci laterales) (Fig. 8C). The paired subiculi fit the symmetrical latero-ventral fossae subiculi.

The rostrum of diverticulum has a distinct lumen (Fig. 8D). The lumen in the posterior part of the rostrum is enlarged and triangle-shaped. Here it divides into three pockets: one ventral and two lateral, enclosed in the saccus ventralis and sacci laterales (Fig. 8C).

\section{Discussion}

The skeleton and the buccal diverticulum are the main supporting structures of collar and proboscis in enteropneusts. In all studied species the proboscis skeleton is a wishbone-like structure with the unpaired anterior plate and paired posterior horns (Spengel, 1893; Van der Horst, 1939). However, the shape of the unpaired plate varies widely in different species of enteropneusts (Fig. 9). In Balanoglossus aurantiacus the unpaired plate is rectangle-shaped (Van der Horst, 1939). In Schizocardium peruvianum the unpaired plate narrows to the anterior end - to subiculi base (Spengel, 1893). In Saccoglossus caraibicus the unpaired plate is rod-shaped and enlarges at the posterior end (Van der Horst, 1939). In S. kowalevskii the unpaired plate is triangle-shaped and enlarges anteriorly (Spengel, 1893). The unpaired plate of $S$. mereschkowskii is rod-shaped and enlarges at the anterior end.

In all studied species of the Enteropneusta the unpaired plate has a mid-ventral keel and more or less pronounced lateral wings. The anterior part of the unpaired plate forms subicu$l i$, but its shape differs even in closely related species. A short rostrum is reported for almost all species except $S$. kowalevskii (Spengel, 1893). S. mereschkowskii has a well pronounced rostrum. Paired subiculi are reported in all species. In all species except $S$. mereschkowskii the terminal areas of subiculi are directed anterior- 

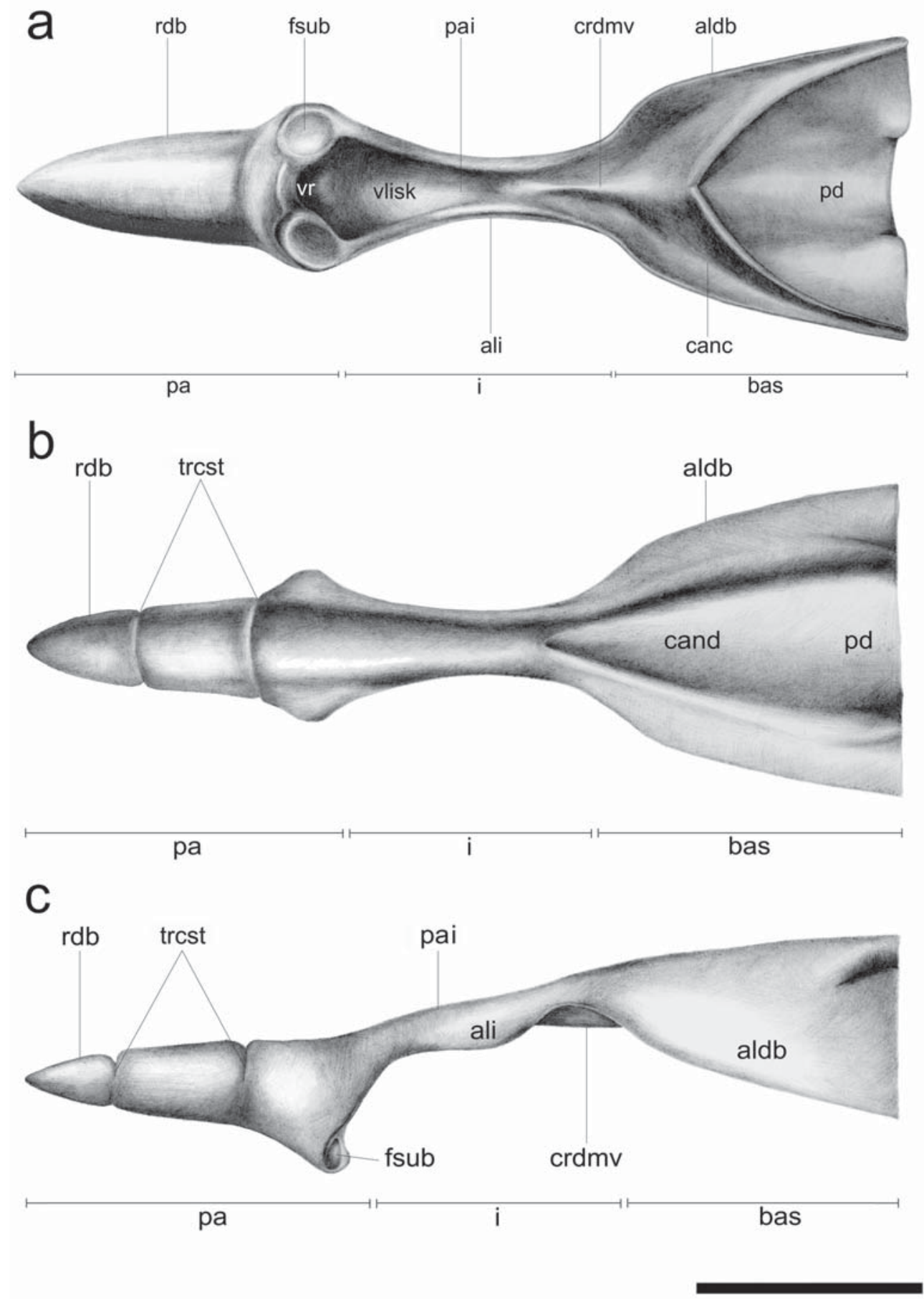

Fig. 6. Buccal diverticulum of Saccoglossus mereschkowskii. A - ventral view; B - dorsal view; C - lateral view. Scale bar $500 \mu \mathrm{m}$. Рис. 6. Буккальный дивертикул Saccoglossus mereschkowskii. А — вид с вентральной стороны; В — вид с дорсальной стороны; С — вид сбоку. Масштаб $500 \mu \mathrm{m}$. 


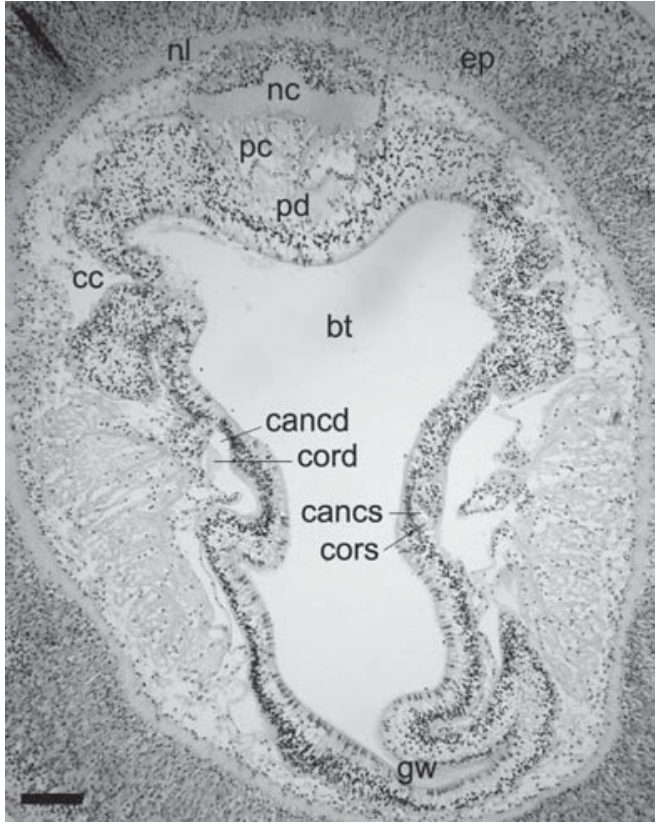

Fig. 7. Transverse section through the collar of Saccoglossus mereschkowskii in the most posterior region of the skeleton.

LM. Scale bar $100 \mu \mathrm{m}$.

Рис. 7. Поперечный срез через воротник Saccoglossus mereschkowskii на уровне самой задней части скелетного элемента.

Световой микроскоп. Масштаб $100 \mu \mathrm{m}$.

ly. However, in S. mereschkowskii the subiculi curved posteriorly.

In most cases the horns bend and taper posteriorly. B. aurantiacus is the only species where the horns enlarge rather then taper posteriorly (Van der Horst, 1939). In B. aurantiacus the horns separate at a widely divergent angle (Fig. 9). In S. kowalevskii, S. caraibicus, and $S$. mereschkowskii the horns curve ventrally towards each other so that the skeleton is lyreshaped.

Some other details of skeleton structure in $S$. mereschkowskii appear unique, but could more likely result from inadequate investigation. For example, the fossa centralis is not reported for most of species. Nevertheless Van der Horst (Van der Horst, 1939) pictured the elongated ventral depression for S. caraibicus which could correspond to fossa centralis of S. meresch- kowskii. More detailed studies of skeleton could supply information useful for enteropneust taxonomy.

The enteropneust buccal diverticulum is divided into three or four regions depending on the species (Spengel, 1893; Willey, 1909; Van der Horst, 1939). Four regions (base, isthmus, anterior part and appendix) are characteristic for Spengelidae only (Spengel, 1893). In Harrimaniidae and Ptychoderidae the appendix is absent, thus the buccal diverticulum is tripartite. Stereobalanus canadensis is reported to lack an isthmus (Van der Horst, 1939).

The morphology of the buccal diverticulum is correlated with the shape of the proboscis skeleton (Fig. 10). The modified diverticulum epithelium is separated from gut epithelium by the skeletal horns, i.e. the epithelium of the buccal diverticulum above and below the skeletal horns is histologically different. In $B$. carnosus, $B$. biminiensis, $B$. jamaicensis, $B$. numeensis, and $B$. gigas the outgrowths of the skeletal plate divide the buccal diverticulum into three separate tubes (Willey, 1899). In Harrimania kupfferi the skeletal outgrowths divide the isthmus into five or six tubes isolated from each other (Spengel, 1893). In S. mereschkowskii the isthmus bears the lateral wings. They look like the lateral pockets in transverse sections and are supported on appropriate skeletal wings (Fig. 11, 12). Such formations are known in other enteropneust species. Strongly developed lateral pockets of the isthmus are present in Glandiceps hacksi (Van der Horst, 1939). In B. misakiensis there are three blind pockets of the isthmus: one dorsal and two dorsolateral (Van der Horst, 1939).

The anterior part of skeleton pushes out the buccal diverticulum tissue, which results in three posteriorly directed blind pockets (Spengel, 1893; Willey, 1899; Van der Horst, 1939). S. mereschkowskii also has such pockets (Fig. 11, 12). Only in Protobalanus koehleri and St. canadensis the blind pockets are absent (Van der Horst, 1939).

Few papers provide a complete reconstruction of the skeletal element in enteropneusts. However, with the information at hand, it is 


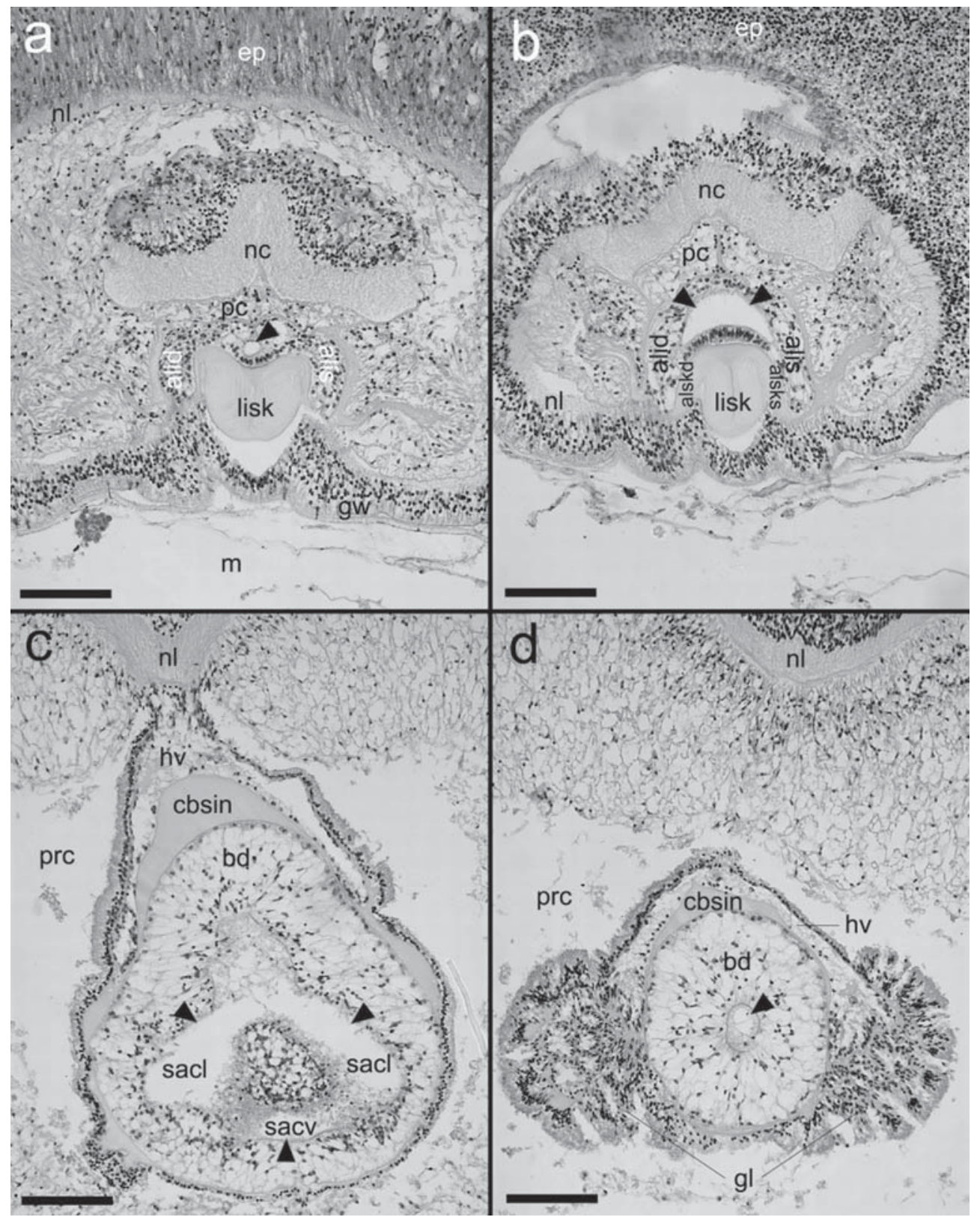

Fig. 8. Transverse sections through the collar (A), stalk (B), and proboscis (C, D) of Saccoglossus mereschkowskii.

LM. Arrows indicate the lumen of the buccal diverticulum. Scale bar $100 \mu \mathrm{m}$.

Рис. 8. Серия поперечных срезов через воротничок (А), стебелёк (В) и хоботок (C, D) Saccoglossus mereschkowskii.

Световой микроскоп. Стрелками указан просвет буккального дивертикула. Масштаб $100 \mu \mathrm{m}$. 


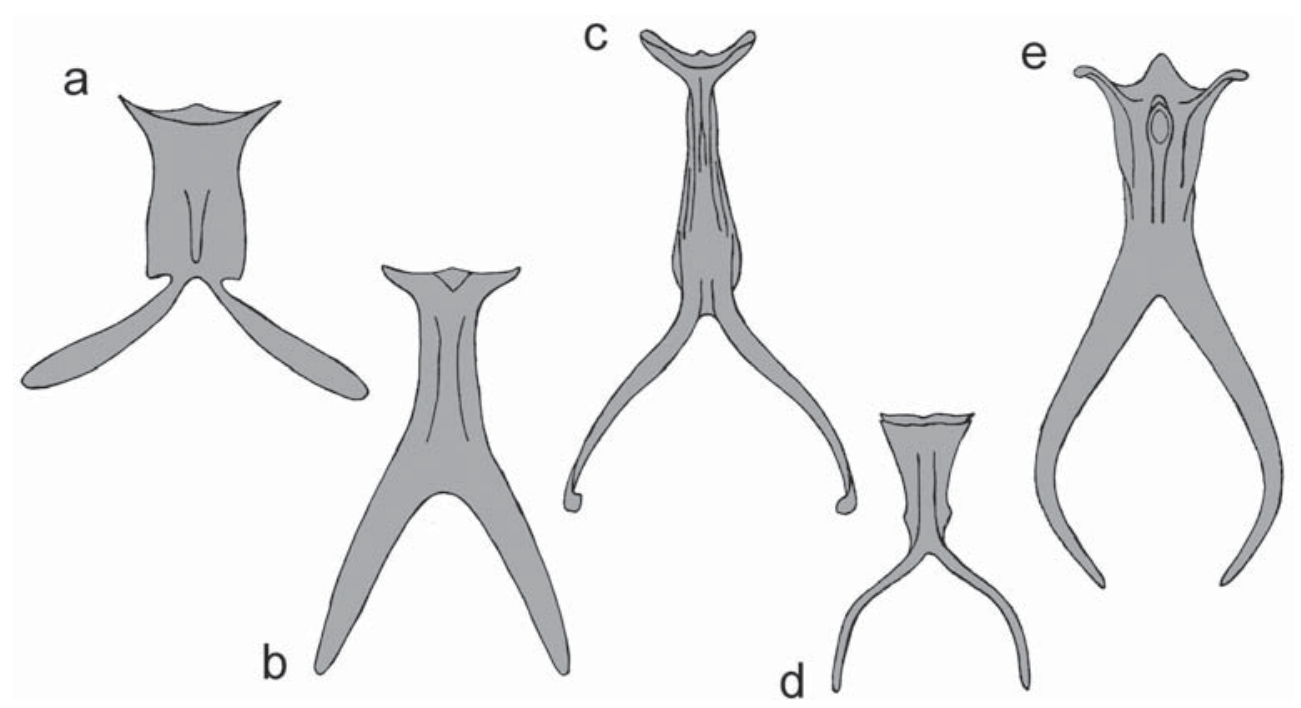

Fig. 9. Schemes of the unpaired skeletons of different enteropneust species. Ventral view.

A - Balanoglossus aurantiacus (Van der Horst, 1939); B - Schizocardium peruvianum (Spengel, 1893); C Saccoglossus caraibicus (Van der Horst, 1939); D - S. kowalevskii (Spengel, 1893); E - S. mereschkowskii.

Рис. 9. Схемы непарных скелетных элементов различных видов кишечнодышащих. Вид с вентральной стороны.

A - Balanoglossus aurantiacus (Van der Horst, 1939); B - Schizocardium peruvianum (Spengel, 1893); C Saccoglossus caraibicus (Van der Horst, 1939); D - S. kowalevskii (Spengel, 1893); E - S. mereschkowskii.

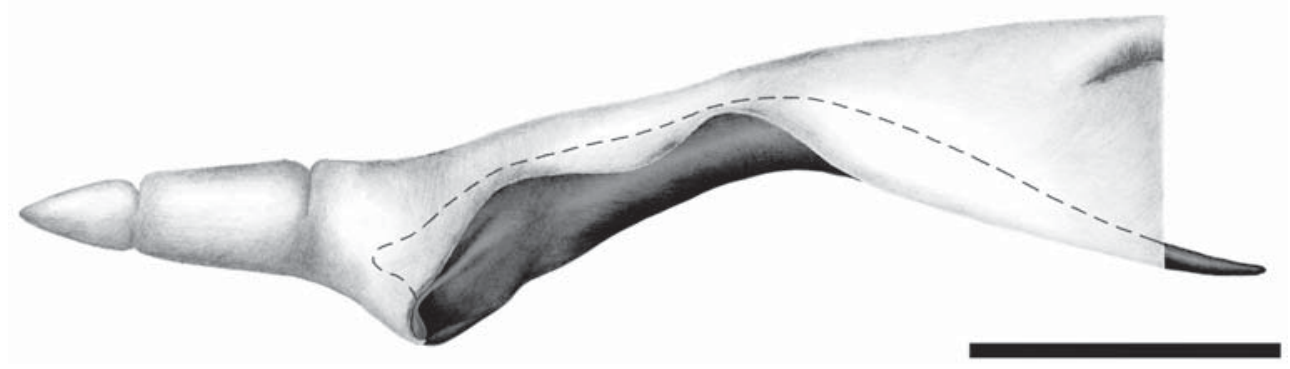

Fig. 10. Relative position of the unpaired skeleton (dark) and the buccal diverticulum (light). Scale bar 500 $\mu \mathrm{m}$.

Рис. 10. Взаимное расположение непарного скелетного элемента (показан тёмным) и буккального дивертикула (показан светлым). Масштаб $500 \mu \mathrm{m}$.

possible to distinguish three groups of enteropneusts according to the shape of their proboscis skeleton (Fig. 9). The first group includes the species of Saccoglossus (Harrimaniidae) (Fig. 9C-E). They have a long lamina imparis and long (more than half of the total skeleton length) lyre-shaped horns which bend around the anterior part of the gut. The long skeletal element is correlated with the relatively long proboscis of Saccoglossus, compared to the other enteropneusts (Hyman, 1959). The long lyre-shaped horns and relatively long lamina imparis pro- 

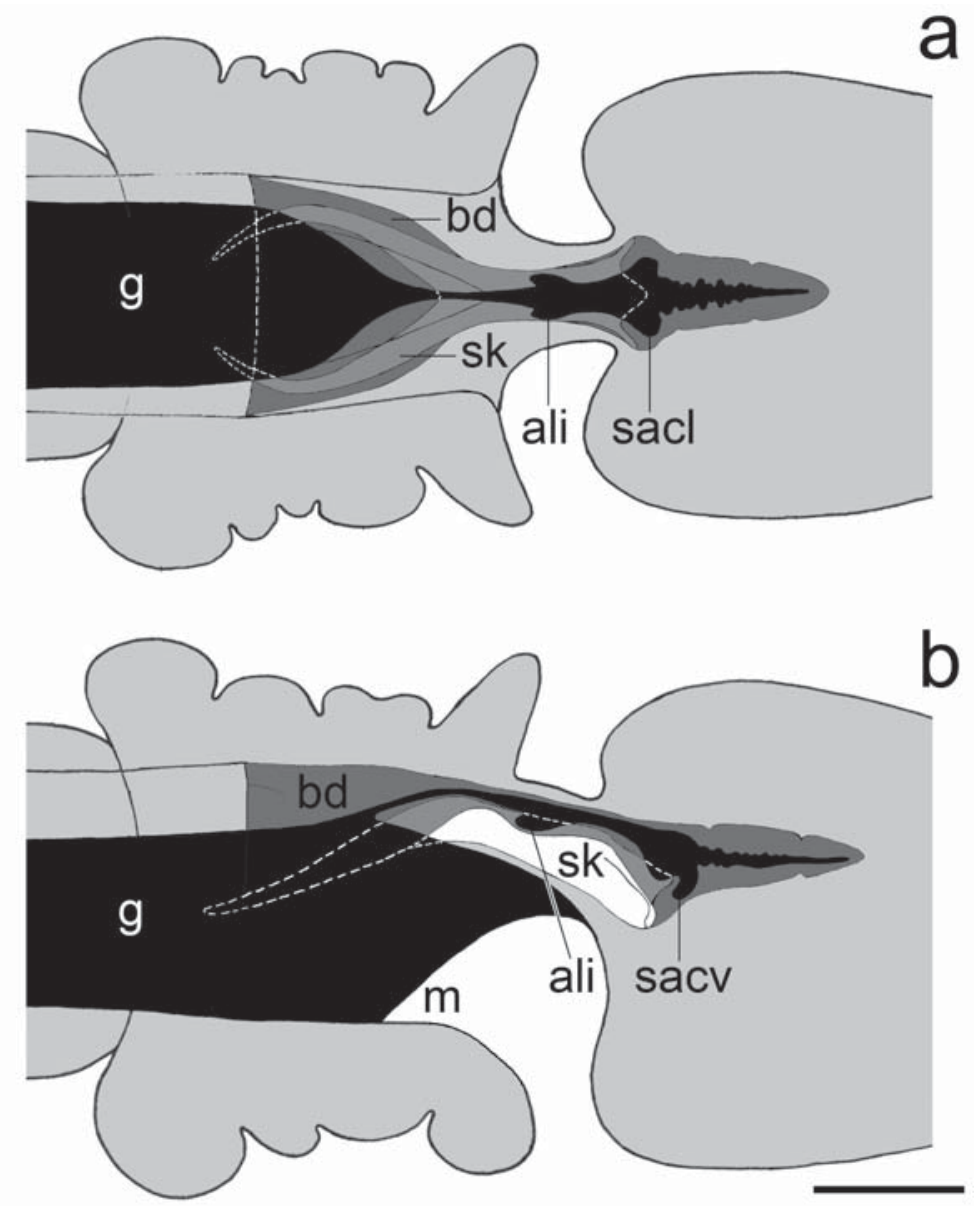

Fig. 11. Shape and location of the lumen (black) of the buccal diverticulum of Saccoglossus mereschkowskii. $\mathrm{a}$ - frontal view; $\mathrm{b}$ - lateral view. Scale bar $500 \mu \mathrm{m}$.

Рис. 11. Форма и расположение просвета (показан чёрным) буккального дивертикула Saccoglossus mereschkowskii.

$\mathrm{a}$ — фронтальный вид; $\mathrm{b}$ — вид сбоку. Масштаб $500 \mu \mathrm{m}$.

vide for mechanical support of the elongated proboscis. The second group inserts the species of Ptychoderidae (Fig. 9A) which are characterized by relatively short proboscis. Accordingly, the skeleton of B. aurantiacus has short, widely separated horns and a broad lamina imparis. The skeleton of specimens of Spengelidae (the third group) has intermediate morphology (Fig. 9B). Sch. peruvianum has a skeleton with short straight horns, but relatively long lamina inpar$i s$. We suggest that the shape of unpaired skeletal element may have a role in enteropneust systematics. However, small number of species with reconstructed skeleton does not allow to discuss this question in more detail.

\section{Acknowledgements}

The work was supported by the Federal Education Agency, contract \# P 1291.

\section{References}

Beklemishev V.N. 1964. [The Foundations of Invertebrate Comparative Anatomy]. Moscow: Nauka. 446 p. [in Russian]. 


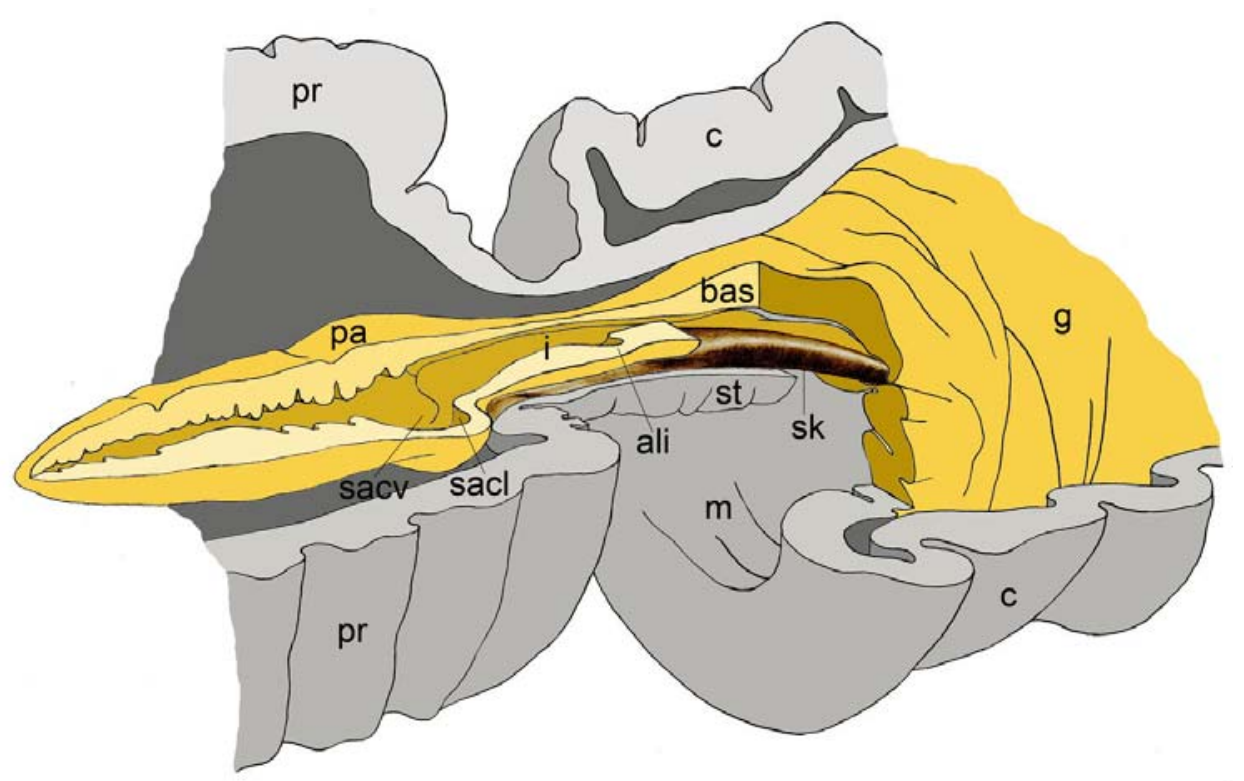

Fig. 12. Three-dimensional reconstruction of the buccal diverticulum and its lumen within the body of Saccoglossus mereschkowskii.

Рис. 12. Трёхмерная реконструкция буккального дивертикула и его просвета в теле Saccoglossus mereschkowskii.

Fedotov D.M. 1966. [The Evolution and Phylogeny of invertebrate animals]. Moscow: Nauka. 404 p. [in Russian].

Ivanov A.V., Polyanskiy U.I., Strelkov A.A. 1981. [The Greater Practical Work of Invertebrate Zoology]. Moskow: Vysshaya Shkola. 504 p. [in Russian].

Bateson W. 1886. The ancestry of the Chordata // Quart. Journ. Micr. Sci. Vol.26. P.535-571.

Benito J., Pardos F. 1997. Hemichordata // F.W. Harrison, E.E. Ruppert (eds.). Microscopic Anatomy of Invertebrates. New York: Wiley-Liss. P.15-101.

Cameron C.B. 2002. The anatomy, life habits, and later development of a new species of enteropneust, Harrimania planktophilus (Hemichordata: Harrimaniidae) from Barkley Sound // Biol. Bull. Vol.202. P.182191.

Cameron C.B., Garey J.R., Swalla B.J. 2000. Evolution of the chordate body plan: new insights from phylogenetic analyses of deuterostome phyla / Proceedings of the National Academy of Sciences of the United States of America. No.97. Vol.9. P.4469-4474.
Hyman L.H. 1959. Hemichordata // L.H. Hyman. The Invertebrates: Smaller Coelomate Groups. New York: McGraw-Hill Book Company. P.72-154.

Jianmey A.N., Xinzheng L.I. 2005. First record of the family Spengeliidae (Hemichordata: Enteropneusta) from Chinese waters, with description of a new species // Journal of Natural History. No.39. Vol.22. P.1995-2004.

Ruppert E.E., Barnes R.D., Fox R.S. 2004. Hemichordata // E.E. Ruppert, R.D. Barnes, R.S. Fox Invertebrate Zoology. Belmont: Thomson Brooks/Cole. P.857-871.

Spengel J.W. 1893. Die Enteropneusten des Golfes von Neapel. Fauna und Flora des Golfes von Neapel. Monogr. $755 \mathrm{p}$.

Van der Horst C.J. 1939. Hemichordata // Bronns K1. Ordn. Tierreichs. Leipzig: Academische Verlagsgesellschaft. S.51-123.

Willey A. 1899. Enteropneusta from the South Pacific, with notes on the West Indian species // M.A. Willey (ed.). Zoological results. Part 3. Cambridge: Cambridge Univ. Press. P.223-334. 